\title{
Collectivistic Norms Facilitate Cooperation but Not Prejudice during a Pandemic
}

\author{
Nan Zhu', Huijing Lu², Lei Chang1 \\ ${ }^{1}$ Department of Psychology, University of Macau, Macau, China \\ ${ }^{2}$ Department of Applied Social Sciences, The Hong Kong Polytechnic University, Hong Kong, China \\ Email: chang@um.edu.mo
}

How to cite this paper: Zhu, N., Lu, H. J., \& Chang, L. (2020). Collectivistic Norms Facilitate Cooperation but Not Prejudice during a Pandemic. Psychology, 11, 1826-1836. https://doi.org/10.4236/psych.2020.1112115

Received: September 2, 2020

Accepted: December 11, 2020

Published: December 14, 2020

Copyright $\odot 2020$ by author(s) and Scientific Research Publishing Inc. This work is licensed under the Creative Commons Attribution International License (CC BY 4.0).

http://creativecommons.org/licenses/by/4.0/

\begin{abstract}
As the world grapples with the coronavirus disease 2019 (COVID-19) pandemic, it is ever more critical to understand how pathogens affect human social behaviors and attitudes. We review recent evidence for the parasite stress theory, which posits that pathogen threats may have led to psychological and cultural adaptations in terms of collectivism and outgroup prejudice. Although there is strong literature support that behavioral immune responses might have contributed to collectivistic norms, the link between pathogen prevalence and outgroup prejudice is less clear. To explain this, we proposed a new hypothesis, arguing that outgroup prejudice as an undesirable side effect of behavioral immune systems might be curtailed by collectivistic norms and centralized authorities, which, in turn, reflect cultural adaptations to cooperation in high-pathogen environments. This perspective provides novel explanations of the cultural difference in the phenomena of xenophobia and racial prejudice during pandemics.
\end{abstract}

\section{Keywords}

Behavioral Immune System, Collectivism, Pathogen Prevalence, Parasite Stress Theory, Prejudice

\section{Background}

The coronavirus disease 2019 (COVID-19) pandemic is by no means the first pathogen scare faced by humans. As Homo sapiens disperse across different geographical regions and encounters new animal species or other conspecific groups, our ancestors were inevitably exposed to novel pathogens against which they have no physiological immunity. As a result, behavioral and psychological mechanisms have evolved to mitigate personal infection risks and to facilitate 
collective efforts to contain the spread of diseases (Fincher \& Thornhill, 2012; Murray, Schaller, \& Suedford, 2013; Murray, Trudeau, \& Schaller, 2011; Schaller \& Park, 2011). These instinctive "behavioral immune responses", nevertheless, have undesirable side effects in modern, heterogeneous societies. For example, people might resort to a conservative or discriminative mindset (e.g., traditionalism and xenophobia), which, in evolutionary history, functions to minimize contacts with outsiders who might spread novel pathogens (Faulkner, Schaller, Park, \& Duncan, 2004; Tybur et al., 2016). This is particularly relevant during the ongoing COVID-19 crisis, as incidents of outgroup prejudice targeting a variety of victims at individual, societal, and political levels are drawing increasing attention (Clissold, Nylander, Watson, \& Ventriglio, 2020; Roberto, Johnson, \& Rauhaus, 2020). As the United Nations Secretary-General Antonio Guterres tweeted, "[the pandemic] unleash a tsunami of hate and xenophobia, scapegoating and scare-mongering" (Guterres, 2020).

\section{Pathogen Prevalence and Collectivistic Norms}

Humans have a long history of coevolving with many kinds of pathogens that cause infectious diseases due to group living and animal husbandry (Diamond, 1997). Pathogens, as a recurrent challenge in evolutionary history, were believed to be instrumental in shaping human behaviors and culture, leading to a "behavioral immune system” (Murray \& Schaller, 2012; Schaller \& Park, 2011). This includes individual-level behavioral proclivities such as heightened risk aversion and social tendencies such as obedience, conformity, and compliance with social norms (Schaller \& Murray, 2008; Wu \& Chang, 2012). The latter aspect was strongly associated with collectivistic cultural norms (rules and expectations shared by people to ensure collective interests; Chen, Wasti, \& Triandis, 2007), thus leading to the speculation that pathogen prevalence might constitute one of the environmental facilitators of collectivism and authoritarian social structures (Chang, Mak, Li, Wu, Chen, \& Lu, 2011; Fincher, Thornhill, Murray, \& Schaller, 2008; Murray et al., 2013).

According to an epidemiological index compiled by Murray and Schaller (2010), which documented the historical prevalence of nine diseases across 230 geographical regions, Asia $(M=0.49, S D=0.38)$ had a much higher pathogen load than Europe $(M=-0.43 ; S D=0.39)$. These historical pathogenic stress levels seem to correspond closely with cultural patterns in terms of collectivism-individualism. Teaching and parenting in East Asian societies heavily emphasize obedience, uniformity, rote learning, and modesty at the cost of autonomy, whereas Western societies (mostly in Europe and North America) emphasize individuation, creativity, and expression (Chang et al., 2011; Zhu \& Chang, 2019). Research has also found societal-level correlations between historic pathogen prevalence and emphases on family ties, behavioral conformity, and compliance with social norms, all of which commonly linked to collectivism (Cashdan \& Steele, 2013; Fincher \& Thornhill, 2012; Fincher, Thornhill, Murray, 
\& Schaller, 2008; Murray \& Schaller, 2012; Murray, Trudeau, \& Schaller, 2011). Fincher and Thornhill (2012)'s research showed that pathogen prevalence in both contemporary and historical times is associated with stronger family ties and religiosity. Cashdan and Steele (2013) found that traditional societies facing high pathogen stress were more likely to socialize children toward collectivist values centered on social learning and interdependence (obedience rather than self-reliance). Importantly, there is little evidence suggesting that collectivistic cultural practices have to do with increased pathogen exposure (the opposite seems to be true; Cashdan \& Steele, 2013).

Finally, collectivistic norms that enforce ritualized behavioral practices have historically served disease-control functions (reviewed in Fabrega Jr., 1997) and might be seen as a society-level behavioral immune system. Empirical evidence has revealed that infection risks are conducive to collectivistic norms, causing individuals to prefer conformity and obedience in others and to respond more negatively toward others who fail to conform (Murray \& Schaller, 2012; Wu \& Chang, 2012). Additionally, authoritarian forms of governance that enforce collective norms and punish individuals deviating from these behavioral traditions might be accepted to a greater degree in regions historically faced greater parasite stress. This is supported by cross-national covariation between pathogens and authoritarian personalities, and the link between pathogen prevalence and authoritarian governance among traditional societies (Murray et al., 2013).

\section{Pathogen Prevalence and Outgroup Prejudice}

According to the parasite stress theory, contacts with members of other groups may introduce potentially deadly pathogens, which hurt the evolutionary fitness of ingroups as they have no immunity to and no knowledge of the novel pathogens. This leads to the speculation that pathogen threats would contribute to outgroup prejudice and xenophobic attitudes (Faulkner et al., 2004). History is replete with anecdotal examples of scapegoating, stigmatization, and xenophobia during and following disease outbreaks. During the height of the black death plague in 14th century Europe, Jewish citizens were blamed for the spread of the plague and accused of "poisoning" water supplies (Markel, 1999). The Chinese Exclusion Act of 1882 was enacted following a smallpox outbreak in San Francisco (Parmet, 2007). More recent examples included outgroup-disfavoring biases following the avian influenza outbreak from 2005 to 2007 (Gilles et al., 2013), the anti-Africa racism in European countries after the Ebola scare in 2014 (Prati \& Pietrantoni, 2016), and xenophobia in the ongoing COVID-19 pandemic (e.g., Sorokowski et al., 2020; Vachuska, 2020). Sometimes, prejudice against outgroups associated with infection risks was activated even before the first case of infection in the country (Rzymski \& Nowicki, 2020). None of these examples, however, establish a long-term link between outgroup prejudice and chronic pathogen prevalence in these regions, which is necessary for the evolution of outgroup-avoiding behavioral immune responses. 
Outgroup avoidance as a behavioral immune response might stem from deep-rooted physiological and emotional reactions (disgust) that drive disease-aversive behaviors (Schaller \& Park, 2011). Research on the "source effect" should that individuals exhibit greater automatic disgust reactions to malodors of strangers than to those of oneself and familiar others (Peng, Chang, \& Zhou, 2013; Stevenson \& Repacholi, 2005). Nevertheless, it is problematic to assume that the threat of diseases invariantly engenders outgroup prejudice. Other experimental studies have shown that not all outgroups are associated with disease-related disgust emotions (Cottrell \& Neuberg, 2005) and that the link between pathogens and outgroup prejudice is contingent on individuals' sensitivity or vulnerability to disease infection (Faulkner et al., 2004; Huang, Sedlovskaya, Ackerman, \& Bargh, 2011; Klavina, Buunk, \& Pollet, 2011; Navarrete \& Fessler, 2006; O’Shea, Watson, Brown, \& Fincher, 2020). Moreover, superficial physical features such as physical deformity and obesity also trigger prejudicial reactions because of their evolutionary connection to diseases, even though people with these features are "ingroups" (Schaller \& Neuberg, 2012).

Findings regarding the purported link between pathogens and ingroup-outgroup biases are not consistent at the cross-society level. For instance, a large-scale 30-nation study (Tybur et al., 2016) found that national parasite stress correlated with higher traditionalism (i.e., adherence to group norms) but not higher social dominance orientation (i.e., endorsements of intergroup barriers and discrimination against ethnic and racial outgroups). Cashdan and Steele (2013) found no association between pathogens and ingroup-outgroup biases (e.g., xenophobia) using the Standard Cross-Cultural Sample of 186 traditional societies. Recent studies that controlling for factors such as government services and material security also found no evidence for ingroup-outgroup biases in societies with higher pathogen stress (Hruschka et al., 2014; Hruschka \& Henrich, 2013; Romano, Balliet, Yamagishi, \& Liu, 2017). Additionally, Tybur et al. (2015) provided evidence that correlations between the degree of outgroup prejudice (measured as social conservatism) and pathogen avoidance motivations can be accounted for by the co-variation between disgust sensitivity and sociosexual orientation. All these findings cast doubt on the assumption that pathogen threats would always motivate negative perceptions of outgroups as a behavioral immune response.

\section{Distinction between Collectivistic Norms and Outgroup Prejudice}

To better understand the relationship between parasite stress and outgroup prejudice, it is important to distinguish between ingroup positivity and outgroup prejudice (Brewer, 1999, 2007). Ingroup-outgroup distinction is not specific to any cultural orientation but underlies group functioning in all human societies (Brewer \& Chen, 2007; Brewer \& Yuki, 2007). Results from both experiments and field studies indicate that favorable attitudes toward ingroups do not corre- 
late with bias or negativity toward outgroups (Yamagishi, Jin, \& Miller, 1998; Reviewed in Brewer, 1999, 2007). Research using minimal group procedures, for instance, generally found that individuals are willing to favor ingroups but are reluctant to directly harm outgroups (e.g., Mummendey et al., 1992; Cameron, Alvarez, Ruble, \& Fuligni, 2001). East Asians living in collectivistic societies were found to be less discriminative against outgroups in minimal-group settings when such behaviors do not manifestly benefit ingroups (Yamagishi et al. 1998). Overall, we can infer that collectivistic norms that emphasize ingroup positivity do not necessarily bring about intergroup antagonism and divisiveness.

On the contrary, collectivistic norms and the relevant suite of psychological adaptations (e.g., respect of rules and authorities) comprise the cornerstone of large-scale cooperation (Chudek \& Henrich, 2011). This is supported by previous research showing that allocentric (collective-minded) individuals acted more cooperatively when there were cooperative norms than there were not. By contrast, idiocentric (individualistic) individuals were not only more focused on self-interests at the expense of the group but also less sensitive to cooperative norms (Chen et al., 2007). Many aspects of collectivism appear to promote large-scale cooperation among people facing the same environmental challenges, such as irrigation projects required by rice-farming (Talhelm et al., 2014) and unmitigated climatic challenges because of the scarcity of economic resources (Van de Vliert, Yang, Wang, \& Ren, 2013). This also applies to the threat of pathogens. Societal preventive measures against communicable diseases necessitate collective efforts organized by central, collective authorities (Murray et al., 2013).

Moreover, outgroup prejudice entails additional costs of foregoing mutually beneficial cooperation opportunities with outgroups (e.g., trade, exchange of knowledge and information, and intergroup mating) and might be counterproductive even in early human society (Zhu, Lu, \& Chang, 2020). Thus, from an evolutionary perspective, outgroup prejudice and distrust should only be invoked when the fitness costs of disease infections outweigh fitness gains from interaction with outgroups.

\section{Collectivistic Norms Reduces Divisiveness in the Face of Disease Threats: A Hypothesis}

For humans, cultural rituals (e.g., related to hygiene, food processing, and social etiquette) have historically served to minimize infection risks (Fabrega Jr., 1997). Although norms and rituals as non-pharmaceutical disease-control efforts are not always effective in the fight against diseases, they are essential to maintain intragroup and intergroup cooperation during epidemics and pandemics, especially when there are no medical solutions for the pathogens. Although the tradeoff between avoidance of infection and intergroup cooperation applies to all cultures, differences in cultural norms derived from historical pathogen prevalence might predict different attitudes and behavioral adjustments in the face of the same pathogen threat. In environments with high pathogen prevalence, 
strong collectivistic norms enforced by authorities might serve to ensure people's adherence to these rules and rituals for the greater good of public health, thus contributing to disease control (Murray et al., 2013). Knowing others are following the same rules and rituals that serve collective interests might relieve worries about communicable diseases, thus causing people to be less prone to resort to outgroup prejudice as a behavioral immune response in collectivistic societies. It is conceivable that disease-prevention interventions and norms that necessitate temporary sacrifices of personal choice and freedoms for the greater good of public health (e.g., quarantines, community closures) might face more psychological backlash in individualistic societies (Zhu, O, Lu, \& Chang, 2020), which historically faced lower pathogen stress (Murray \& Schaller, 2010). Emerging evidence indeed did show that collectivism is associated with better psychological adjustment in the face of the COVID-19 pandemic and accompanying societal regulations among young adults (Germani, Buratta, Delvecchio, \& Mazzeschi, 2020).

Further, collectivistic norms and collective authorities might serve as social glues that bind people together in the face of common threats of infectious diseases, essentially mitigating intergroup tensions and maintain large-scale cooperation. Collectivistic cultures emphasize social-learning strategies such as conformity (i.e., preferentially copying the most widely accepted solution or following the majority) and compliance (i.e., preferentially copying high-prestige models or following leaders; Boyd \& Richerson, 2005). Such conformist and prestige biases (Boyd \& Richerson, 2005) should allow central authorities in collectivistic societies to mobilize the public and maintain social order despite the implementation of drastic societal preventive measures after disease outbreaks. For instance, within a few weeks after the initial report of the outbreak in $\mathrm{Wu}$ han, thousands of medical staff and health professionals from all overall China were deployed to Hubei (the initial epicenter of the pandemic) to help the local hospitals fight against the COVID-19 threat (The Star, 2020). Such concentrated efforts organized by the central authority boosted inter-province cooperation and essentially mitigated the possibility of regional discrimination and stigmatization of people from provinces most affected by COVID-19 outbreaks. Ultimately, collectivistic norms, by maintaining cooperation and rooting out prejudice, can be seen as an extension of the behavioral immune system that not only reduces infection risks but also enhances societal members' fitness via increasing cooperative opportunities in high-pathogen environments. More empirical research is needed to test this postulation, but it carries profound implications for public health policymaking during the current COVID-19 pandemic.

The same disease threats might undermine intergroup cooperation in individualistic societies that historically faced lower parasite stress (Murray \& Schaller, 2010) and thus, are reluctant to adopt collectivistic norms. Recent empirical evidence indicated that racial prejudice and xenophobia are likely to rise in predominantly individualistic societies (e.g., Poland, the United Kingdom, and the 
United States) during pandemics (Croucher, Nguyen, \& Rahmani, 2020; Rzymski \& Nowicki, 2020; Sorokowski et al., 2020; Tabri, Hollingshead, \& Wohl, 2020; Vachuska, 2020). More relevantly, a study informed by the pathogen-prevalence hypothesis showed that the association between xenophobic attitudes and increased vulnerability was especially pronounced among people scoring high in individualism and low in collectivism (Kim, Sherman, \& Updegraff, 2016).

Outgroup prejudice as a side effect of the common behavioral immune system may be more common in individualistic societies, where there are pre-existing prejudices associating outgroups to diseases and pathogens (Clissold et al., 2020; Roberto et al., 2020). Individualistic cultures, which typically emphasize autonomy, independence, and nonconformity (Kim \& Markus, 1999; Talhelm et al., 2014) tend to emphasize independent solutions and trust in individuals, not authorities and norms (Chang et al., 2011; Yamagishi et al., 1998). Without a central authority to maintain cooperation beyond immediate ingroups, individuals might easily justify pre-existing outgroup prejudice by associating outgroups with infection risks (even when there is no epidemiological link), especially when they experience high levels of anxiety and threats. This is supported by recent research (Tabri et al., 2020), which showed that framing COVID-19 as an existential threat, compared with framing it as non-threat, increased American participants' anxiety, which, in turn, predicted heightened prejudice against outgroups purportedly linked to infection risks (Chinese people).

In summary, there is considerable empirical evidence linking pathogen prevalence to collectivism. However, the collectivistic norm that benefits ingroups do not necessarily indicate outgroup discrimination. Outgroup prejudice as an undesirable side effect of behavioral immune systems might be more common in individualistic societies that lack a centralized disease-prevention effort. One reason for this might be that collectivistic norms derived from high-pathogen environments not only serve to reduce infection risks but also constitutes a social mechanism to maintain cooperation and mitigate discrimination in the face of pathogen threats. To conclude, understanding how cultural and social structural factors affect the manifestation of different behavioral immune responses is particularly relevant during the current COVID-19 pandemic. While it is human nature to fear infections from other people, this does not mean we cannot maintain social cooperation and inclusion during a pandemic. After all, division and fear of others will only lead to worse outcomes for all, and cooperation and solidarity are the ultimate "medicine" for a pandemic.

\section{Acknowledgments}

The authors declare that they have no conflict of interest and received no funding when submitting this paper.

\section{Conflicts of Interest}

The authors declare no conflicts of interest regarding the publication of this paper. 


\section{References}

Boyd, R., \& Richerson, P. J. (2005). The Origin and Evolution of Cultures. New York, NY: Oxford University Press.

Brewer, M. B. (1999). The Psychology of Prejudice: Ingroup Love and Outgroup Hate? Journal of Social Issues, 55, 429-444. https://doi.org/10.1111/0022-4537.00126

Brewer, M. B. (2007). The Importance of Being We: Human Nature and Intergroup Relations. American Psychologist, 62, 728-738. https://doi.org/10.1037/0003-066X.62.8.728

Brewer, M. B., \& Chen, Y.-R. (2007). Where (Who) Are Collectives in Collectivism? Toward Conceptual Clarification of Individualism and Collectivism. Psychological Review, 114, 133-151. https://doi.org/10.1037/0033-295X.114.1.133

Brewer, M. B., \& Yuki, M. (2007). Culture and Social Identity. In S. Kitayama, \& D. Cohen (Eds.), Handbook of Cultural Psychology (pp. 307-322). New York, NY: Guilford.

Cameron, J. A., Alvarez, J. M., Ruble, D. N., \& Fuligni, A. J. (2001). Children's Lay Theories about Ingroups and Outgroups: Reconceptualizing Research on Prejudice. Personality and Social Psychology Review, 5, 118-128. https://doi.org/10.1207/S15327957PSPR0502_3

Cashdan, E., \& Steele, M. (2013). Pathogen Prevalence, Group Bias, and Collectivism in the Standard Cross-Cultural Sample. Human Nature, 24, 59-75. https://doi.org/10.1007/s12110-012-9159-3

Chang, L., Mak, M. C. K., Li, T., Wu, B. P., Chen, B. B., \& Lu, H. J. (2011). Cultural Adaptations to Environmental Variability: An Evolutionary Account of East-West Differences. Educational Psychology Review, 23, 99-129.

https://doi.org/10.1007/s10648-010-9149-0

Chen, X. P., Wasti, S. A., \& Triandis, H. C. (2007). When Does Group Norm or Group Identity Predict Cooperation in a Public Goods Dilemma? The Moderating Effects of Idiocentrism and Allocentrism. International Journal of Intercultural Relations, 31, 259-276. https://doi.org/10.1016/j.ijintrel.2006.02.004

Chudek, M., \& Henrich, J. (2011). Culture-Gene Coevolution, Norm-Psychology and the Emergence of Human Prosociality. Trends in Cognitive Sciences, 15, 218-226.

https://doi.org/10.1016/j.tics.2011.03.003

Clissold, E., Nylander, D., Watson, C., \& Ventriglio, A. (2020). Pandemics and Prejudice. International Journal of Social Psychiatry, 66, 421-423. https://doi.org/10.1177/0020764020937873

Cottrell, C. A., \& Neuberg, S. L. (2005). Different Emotional Reactions to Different Groups: A Sociofunctional Threat-Based Approach to "Prejudice". Journal of Personality and Social Psychology, 88, 770-789. https://doi.org/10.1037/0022-3514.88.5.770

Croucher, S. M., Nguyen, T., \& Rahmani, D. (2020). Prejudice toward Asian Americans in the Covid-19 Pandemic: The Effects of Social Media Use in the United States. Frontiers in Communication, 5, Article No. 39. https://doi.org/10.3389/fcomm.2020.00039

Diamond, J. (1997). Guns, Germs, and Steel: The Fates of Human Societies. New York, NY: W. W. Norton \& Company.

Fabrega Jr., H. (1997). Earliest Phases in the Evolution of Sickness and Healing. Medical Anthropology Quarterly, 11, 26-55. https://doi.org/10.1525/maq.1997.11.1.26

Faulkner, J., Schaller, M., Park, J. H., \& Duncan, L. A. (2004). Evolved Disease-Avoidance Mechanisms and Contemporary Xenophobic Attitudes. Group Processes \& Intergroup Relations, 7, 333-353. https://doi.org/10.1177/1368430204046142

Fincher, C. L., \& Thornhill, R. (2012). Parasite-Stress Promotes in-Group Assortative So- 
ciality: The Cases of Strong Family Ties and Heightened Religiosity. Behavioral and Brain Sciences, 35, 61-79. https://doi.org/10.1017/S0140525X11000021

Fincher, C. L., Thornhill, R., Murray, D. R., \& Schaller, M. (2008). Pathogen Prevalence Predicts Human Cross-Cultural Variability in Individualism/Collectivism. Proceedings of the Royal Society B: Biological Sciences, 275, 1279-1285.

https://doi.org/10.1098/rspb.2008.0094

Germani, A., Buratta, L., Delvecchio, E., \& Mazzeschi, C. (2020). Emerging Adults and COVID-19: The Role of Individualism-Collectivism on Perceived Risks and Psychological Maladjustment. International Journal of Environmental Research and Public Health, 17, 3497. https://doi.org/10.3390/ijerph17103497

Gilles, I., Bangerter, A., Clémence, A., Green, E. G. T., Krings, F., Mouton, A., Rigaud, D., Staerklé, C., \& Wagner-Egger, P. (2013). Collective Symbolic Coping with Disease Threat and Othering: A Case Study of Avian Influenza. British Journal of Social Psychology, 52, 83-102. https://doi.org/10.1111/j.2044-8309.2011.02048.x

Guterres, A. (2020). COVID-19 Does Not Care Who We Are, Where We Live, or What We Believe [Tweet; Attached Video]. Twitter.

https://twitter.com/antonioguterres/status/1258613180030431233?lang=en

Hruschka, D. J., \& Henrich, J. (2013). Institutions, Parasites and the Persistence of In-Group Preferences. PLoS One, 8, e63642. https://doi.org/10.1371/journal.pone.0063642

Hruschka, D., Efferson, C., Jiang, T., Falletta-Cowden, A., Sigurdsson, S., McNamara, R., Sands, M., Munira, S., Slingerland, E., \& Henrich, J. (2014). Impartial Institutions, Pathogen Stress and the Expanding Social Network. Human Nature, 25, 567-579.

https://doi.org/10.1007/s12110-014-9217-0

Huang, J. Y., Sedlovskaya, A., Ackerman, J. M., \& Bargh, J. A. (2011). Immunizing against Prejudice: Effects of Disease Protection on Attitudes toward Out-Groups. Psychological Science, 22, 1550-1556. https://doi.org/10.1177/0956797611417261

Kim, H. S., Sherman, D. K., \& Updegraff, J. A. (2016). Fear of Ebola: The Influence of Collectivism on Xenophobic Threat Responses. Psychological Science, 27, 935-944. https://doi.org/10.1177/0956797616642596

Kim, H., \& Markus, H. R. (1999). Deviance or Uniqueness, Harmony or Conformity? A Cultural Analysis. Journal of Personality and Social Psychology, 77, 785-800. https://doi.org/10.1037/0022-3514.77.4.785

Klavina, L., Buunk, A. P., \& Pollet, T. V. (2011). Out-Group Mating Threat and Disease Threat Increase Implicit Negative Attitudes toward the Out-Group among Men. Frontiers in Psychology, 2, Article No. 76. https://doi.org/10.3389/fpsyg.2011.00076

Markel, H. (1999). Quarantine! East European Jewish Immigrants and the New York City Epidemics of 1892 (1st ed.). Baltimore, MD: Johns Hopkins University Press.

Mummendey, A., Simon, B., Dietze, C., Grunert., M., Haeger, G., Kessler, S., Lettgen, S., \& Schäferhoff, S. (1992). Categorization Is Not Enough: Intergroup Discrimination in Negative Outcome Allocations. Journal of Experimental Social Psychology, 128, 125-144. https://doi.org/10.1016/0022-1031(92)90035-I

Murray, D. R., \& Schaller, M. (2010). Historical Prevalence of Infectious Diseases within 230 Geopolitical Regions: A Tool for Investigating Origins of Culture. Journal of Cross-Cultural Psychology, 41, 99-108. https://doi.org/10.1177/0022022109349510

Murray, D. R., \& Schaller, M. (2012). Threat(s) and Conformity Deconstructed: Perceived Threat of Infectious Disease and Its Implications for Conformist Attitudes and Behavior. European Journal of Social Psychology, 42, 180-188.

https://doi.org/10.1002/ejsp.863

Murray, D. R., Schaller, M., \& Suedfeld, P. (2013). Pathogens and Politics: Further Evi- 
dence That Parasite Prevalence Predicts Authoritarianism. PLoS ONE, 8, e62275. https://doi.org/10.1371/journal.pone.0062275

Murray, D. R., Trudeau, R., \& Schaller, M. (2011). On the Origins of Cultural Differences in Conformity: Four Tests of the Pathogen Prevalence Hypothesis. Personality and Social Psychology Bulletin, 37, 318-329. https://doi.org/10.1177/0146167210394451

Navarrete, C. D., \& Fessler, D. M. (2006). Disease Avoidance and Ethnocentrism: The Effects of Disease Vulnerability and Disgust Sensitivity on Intergroup Attitudes. Evolution and Human Behavior, 27, 270-282. https://doi.org/10.1016/j.evolhumbehav.2005.12.001

O’Shea, B. A., Watson, D. G., Brown, G. D., \& Fincher, C. L. (2020). Infectious Disease Prevalence, Not Race Exposure, Predicts Both Implicit and Explicit Racial Prejudice across the United States. Social Psychological and Personality Science, 11, 345-355. https://doi.org/10.1177/1948550619862319

Parmet, W. E. (2007). Legal Power and Legal Rights-Isolation and Quarantine in the Case of Drug-Resistant Tuberculosis. New England Journal of Medicine, 357, 433-435. https://doi.org/10.1056/NEJMp078133

Peng, M., Chang, L., \& Zhou, R.L. (2013). Physiological and Behavioral Responses to Strangers Compared to Friends as a Source of Disgust. Evolution and Human Behavior, 34, 94-98. https://doi.org/10.1016/j.evolhumbehav.2012.10.002

Prati, G., \& Pietrantoni, L. (2016). Knowledge, Risk Perceptions, and Xenophobic Attitudes: Evidence from Italy during the Ebola Outbreak. Risk Analysis, 36, 2000-2010. https://doi.org/10.1111/risa.12537

Roberto, K. J., Johnson, A. F., \& Rauhaus, B. M. (2020). Stigmatization and Prejudice during the COVID-19 Pandemic. Administrative Theory \& Praxis, 42, 364-378. https://doi.org/10.1080/10841806.2020.1782128

Romano, A., Balliet, D., Yamagishi, T., \& Liu, J. H. (2017). Parochial Trust and Cooperation across 17 Societies. Proceedings of the National Academy of Sciences of the United States of America, 114, 12702-12707. https://doi.org/10.1073/pnas.1712921114

Rzymski, P., \& Nowicki, M. (2020). COVID-19-Related Prejudice towards Asian Medical Students: A Consequence of SARS-CoV-2 Fears in Poland. Journal of Infection and Public Health, 13, 873-876. https://doi.org/10.1016/j.jiph.2020.04.013

Schaller, M., \& Murray, D. R. (2008). Pathogens, Personality, and Culture: Disease Prevalence Predicts Worldwide Variability in Sociosexuality, Extraversion, and Openness to Experience. Journal of Personality and Social Psychology, 95, 212-221. https://doi.org/10.1037/0022-3514.95.1.212

Schaller, M., \& Neuberg, S. L. (2012). Danger, Disease, and the Nature of Prejudice(s). Advances in Experimental Social Psychology, 46, 1-54. https://doi.org/10.1016/B978-0-12-394281-4.00001-5

Schaller, M., \& Park, J. H. (2011). The Behavioral Immune System (and Why It Matters). Current Directions in Psychological Science, 20, 99-103. https://doi.org/10.1177/0963721411402596

Sorokowski, P., Groyecka, A., Kowal, M., Sorokowska, A., Białek, M., Lebuda, I., Zdybek, P., \& Karwowski, M. (2020). Can Information about Pandemic Increases Negative Attitudes toward Foreign Groups: A Case of COVID-19 Outbreak. Sustainability, 12, 4912. https://doi.org/10.31234/osf.io/j23vt

Stevenson, R. J., \& Repacholi, B. M. (2005). Does the Source of an Interpersonal Odour Affect Disgust? A Disease Risk Model and Its Alternatives. European Journal of Social Psychology, 35, 375-401. https://doi.org/10.1002/ejsp.263

Tabri, N., Hollingshead, S., \& Wohl, M. (2020). Framing Covid-19 as an Existential 
Threat Predicts Anxious Arousal and Prejudice towards Chinese People. PsyArXiv. https://psyarxiv.com/mpbtr/

Talhelm, T., Zhang, X., Oishi, S., Shimin, C., Duan, D., Lan, X., \& Kitayama, S. (2014). Large-Scale Psychological Differences within China Explained by Rice versus Wheat Agriculture. Science, 344, 603-608. https://doi.org/10.1126/science.1246850

The Star (2020). Wuhan Virus: China Mobilises Medical Teams to Fight New Coronavirus. The Star.

https://www.thestar.com.my/news/nation/2020/01/26/wuhan-virus-china-mobilises-m edical-teams-to-fight-new-coronavirus

Tybur, J. M., Inbar, Y., Aarøe, L., Barclay, P., Barlow, F. K., De Barra, M., Consedine, N. S. et al. (2016). Parasite Stress and Pathogen Avoidance Relate to Distinct Dimensions of Political Ideology across 30 Nations. Proceedings of the National Academy of Sciences of the United States of America, 113, 12408-12413.

https://doi.org/10.1073/pnas.1607398113

Tybur, J. M., Inbar, Y., Güler, E., \& Molho, C. (2015). Is the Relationship between Pathogen Avoidance and Ideological Conservatism Explained by Sexual Strategies? Evolution and Human Behavior, 36, 489-497.

https://doi.org/10.1016/j.evolhumbehav.2015.01.006

Vachuska, K. (2020). Initial Effects of the Coronavirus Pandemic on Racial Prejudice in the United States. Evidence from Google Trends. https://osf.io/preprints/socarxiv/bgpk3/.

Van de Vliert, E., Yang, H., Wang, Y., \& Ren, X. P. (2013). Climato-Economic Imprints on Chinese Collectivism. Journal of Cross-Cultural Psychology, 44, 589-605. https://doi.org/10.1177/0022022112463605

Wu, B. P., \& Chang, L. (2012). The Social Impact of Pathogen Threat: How Disease Salience Influences Conformity. Personality and Individual Differences, 53, 50-54. https://doi.org/10.1016/j.paid.2012.02.023

Yamagishi, T., Jin, N., \& Miller, A. S. (1998). In-Group Bias and Culture of Collectivism. Asian Journal of Social Psychology, 1, 315-328. https://doi.org/10.1111/1467-839X.00020

Zhu, N. \& Chang, L. (2019). Education and Parenting in China. In E. Sorbing, \& J. E. Lansford (Eds.), School Systems, Parental Behavior, and Academic Achievement: An International Perspective (pp. 15-28). Cham: Springer Nature. https://doi.org/10.1007/978-3-030-28277-6_2

Zhu, N., Lu, H. J., \& Chang, L. (2020). Trust as Social Investment: A Life-History Model of Environmental Effects on Ingroup and Outgroup Trust. Personality and Individual Differences, 168, Article ID: 110303. https://doi.org/10.1016/j.paid.2020.110303

Zhu, N., O, J. Q., Lu, H. J., \& Chang, L. (2020). Debate: Facing Uncertainty with (out) a Sense of Control-Cultural Influence on Adolescents' Response to the COVID-19 Pandemic. Child and Adolescent Mental Health, 25, 173-174.

https://doi.org/10.1111/camh.12408 